\title{
ENTRE A REDAÇÃO E O SET DE FILMAGEM: A CIRCULAÇÃO DO PENSAMENTO FEMINISTA NA DITADURA CIVIL- MILITAR (1970/1980)
}

\section{Nayla Tavares Guerra*}

DOI: 10.11606/issn.2318-8855.v10i1p78-110

Resumo: O presente artigo parte do recorte da ditadura civil-militar para investigar a circulação do pensamento feminista em dois meios de comunicação: os curtametragens feitos por diretoras brasileiras e dois jornais pertencentes à imprensa alternativa feminista: Nós Mulheres (1976 a 1978) e Mulherio (1981 a 1987). Essa análise é calcada na investigação da bibliografia ligada aos estudos de gênero, ao cinema e à imprensa alternativa. No texto apresentado, trataremos em primeiro lugar das produções cinematográficas e jornalísticas estudadas e das questões implicadas em seu resgate. Em seguida, apresentamos a análise do curta Mulheres da Boca (Inês Castilho, Cida Aidar, 1981), produzido por uma equipe que também escrevia para os periódicos. Neste processo, o olhar para os jornais revelou-se bastante frutífero para a investigação das lacunas deixadas pela historiografia, no que concerne às diversas relações entre os filmes e pautas do movimento feminista de segunda onda.

Palavras-chaves: Curta-metragem, Ditadura civil-militar, Feminismo, História do cinema brasileiro, Imprensa alternativa.

* Graduanda no Curso Superior do Audiovisual, ECA-USP. Email para contato: naylaguerra@usp.br. Este artigo é fruto de uma pesquisa de Iniciação Científica orientada pelo Prof. Dr. Eduardo Morettin e financiada pela Fundação de Amparo à Pesquisa do Estado de São Paulo - FAPESP. 


\section{artigos}

\section{Entre a redação e o set de filmagem}

\section{Introdução}

Quão longe teremos de ir para descobrir por onde começar? Olhamos nos livros de história e não há sinal de nós. O que podemos lembrar? Só temos nossas memórias e as histórias que contamos umas às outras.

É com esta reflexão que a cineasta carioca Helena Solberg inicia seu primeiro média-metragem, realizado em 1974 nos Estados Unidos, The emerging woman. Nesta passagem, a diretora questiona a invisibilização da história das mulheres e introduz os desafios da coleta de material para traçar o seu papel na sociedade estadunidense desde o século XVIII até a década de 1970. Questionamentos como este impulsionam estudos que colocam o gênero no centro da análise e tecem uma crítica ao apagamento da participação de mulheres na história. Graças a esses esforços, a história do cinema brasileiro está sendo recontada, processo para o qual pretendemos contribuir por meio desta pesquisa.

Estes novos olhares permitiram que cineastas como Solberg, Ana Carolina, Adélia Sampaio e Teresa Trautman, que iniciaram suas carreiras como diretoras nas décadas de 1960 e 1970, fossem recuperadas e estudadas, evidenciando o apagamento ao qual foram relegadas. Ocorre que a visibilidade conquistada por elas está intrinsecamente ligada ao fato de terem feito ao menos um longa-metragem. Seus curta e média-metragens, porém, permanecem pouco revisitados. A entrevista (Helena Solberg, 1966), "marco fundante do cinema brasileiro moderno de autoria feminina" (HOLANDA, 2017, p. 50), é uma das poucas exceções a este quadro. A despeito da atenção que vem sendo dada a $A$ entrevista, tantos outros curtametragens feitos por diretoras brasileiras no mesmo período permanecem desconhecidos ou não estudados, muitos deles perdidos. Isso se dá, pois, historicamente, aos filmes curtos é atribuída menor importância política, cultural e 


\section{artigos}

\section{Nayla Tavares Guerra}

social, independentemente de sua época de produção (DEBS, 1989, p. 2). Contudo, é neles que as mulheres tinham e têm mais espaço de realização, sendo fundamental lançar um olhar para essas produções ao se estudar o cinema feito por mulheres.

A partir dessa constatação, realizamos um levantamento dos curta-metragens ${ }^{1}$ feitos por diretoras brasileiras no período da ditadura civil-militar. Vale ressaltar que não encontramos curtas feitos antes de $A$ entrevista, realizado em 1966, fato que justifica o começo do recorte temporal de nossa pesquisa neste ano e não em 1964, momento do golpe militar. Dentro do recorte estabelecido, foram encontrados 224 filmes realizador por 123 diretoras diferentes ${ }^{2}$. As obras foram descobertas a partir de um processo de escavação em textos e acervos. Iniciamos essa busca nos debruçando sobre produções acadêmicas que abordam o cinema de longa-metragem feito por diretoras brasileiras, nas quais foram encontrados nomes de mulheres que fizeram filmes durante a ditadura civil-militar. Na medida em que descobríamos estes nomes, buscávamos suas filmografias, o que permitiu constatar que quase todas elas tinham também realizado curtas-metragens.

É o caso de Ana Carolina, diretora mencionada em diversas pesquisas encontradas. Apesar da imensa maioria das menções referirem-se a seus filmes de maior duração, notamos que ela também fez diversos curta-metragens no período estudado. Além disso, percebemos que, ao descobrir um novo curta, ele abria um leque de outras possibilidades, uma vez que, ao estudar sua equipe técnica, constatávamos que as mulheres presentes, não raro, tinham também trabalhado na função de direção em outros projetos. Assim, a cada novo filme encontrado, diversos

\footnotetext{
${ }^{1}$ Consideramos apenas filmes com até 30 minutos, rodados em $16 \mathrm{~mm}$ ou $35 \mathrm{~mm}$.

${ }^{2}$ Percebemos uma facilidade maior de encontrar filmes (tanto as cópias, quanto informações sobre a obra) codirigidos por um homem. Optamos por não incorporá-los ao levantamento realizado, por entendermos que tinham um vínculo diferente com o apagamento de mulheres na história do cinema brasileiro.
} 


\section{artigos}

\section{Entre a redação e o set de filmagem}

outros eram descobertos.

Observamos, no levantamento realizado, uma forte presença de curtametragens que abordavam questões relacionadas a gênero, em diálogo com a chamada segunda onda feminista, iniciada na segunda metade dos anos 1970. Como aponta Ana Maria Veiga (2013), durante o período estudado (1966 a 1985), as cineastas brasileiras eram influenciadas por um "duplo contexto": elas estavam sob o jugo da ditadura civil-militar, ao mesmo tempo em que recebiam os influxos da segunda onda feminista. Com o objetivo de entender de que modo este movimento interferiu nas obras estudadas, nos debruçamos sobre a imprensa feminista alternativa da época, a partir dos jornais Nós Mulheres e Mulherio. Uma relação estreita entre os jornais e os filmes estudados é estabelecida pelo curta-metragem Mulheres da boca (Cida Ainda, Inês Castilho, 1981), realizado no seio do coletivo que editava o Nós Mulheres.

Nesse artigo, traremos algumas conexões entre a imprensa alternativa feminista e os curta-metragens feitos por diretoras brasileiras durante a ditadura civilmilitar. Compreendendo a relevância de Mulheres da boca para este estudo, apresentaremos um comentário mais extenso sobre a obra, mesclando análise fílmica com dados encontrados nos jornais.

\section{O pessoal é político: movimento feminista, imprensa alternativa e curta-metragens}

A instauração da ditadura civil-militar, em 1964, desencadeou uma mudança radical na política brasileira. Movimentos populares, como os camponeses e os sindicalistas, foram fortemente reprimidos, assim como professores, advogados, jornalistas e estudantes (TELES, 1993, p. 61). O contexto foi marcado pela forte interferência militar, pelas violações aos direitos humanos, pela censura, pelos 


\section{artigos}

Nayla Tavares Guerra

atentados contra a liberdade de expressão e pela difusão de um projeto moral baseado na centralidade da família nuclear, nos valores heteronormativos e na subordinação das mulheres aos homens (DUARTE, 2013, apud CAVALCANTE, 2017, p. $59)$.

Nesse cenário, ressurgem as discussões sobre gênero no $\mathrm{Brasil}^{3}$, em diálogo com os debates que vinham sendo travados nos Estados Unidos e nos países europeus, sobretudo a partir das publicações de Simone de Beauvoir ( $O$ segundo sexo, 1949) e Betty Friedan (A mística feminina, 1943). No Brasil, as feministas contestavam radicalmente "o modelo de feminilidade difundido pela sociedade, que atribuía às mulheres os papéis de esposa, mãe e filha, mantendo-as submetidas ao domínio masculino, como coadjuvantes ou auxiliares dos homens no âmbito público ou no privado" (CAVALCANTE, 2017, p. 60). Temas antes considerados privados e individuais passam a ser incluídos no debate público a partir da ideia de que o pessoal é político. Com isso, a opressão vivenciada pelas mulheres no âmbito doméstico começa a ser compreendida, pelos movimentos feministas, como pertencente a uma opressão estrutural e coletiva, que não poderia ser solucionada individualmente. Como expressado por Pateman,

[...] as circunstâncias pessoais estão estruturadas por fatores públicos, por leis sobre a violação e o aborto, pelo status de 'esposa', por políticas relativas ao cuidado das crianças, pela definição de subsídios próprios do estado de bem estar e pela divisão sexual do trabalho no lar e fora dele. Portanto, os problemas 'pessoais' só podem ser resolvidos através dos meios e das ações políticas (PATEMAN, 1996, p. 47, apud COSTA, 2010, p. 176).

\footnotetext{
${ }^{3}$ Essas discussões já haviam aparecido no contexto brasileiro no início do século XXI, com a luta pelo direito ao voto feminino, que agrupou uma parcela expressiva de mulheres. "Pertencentes à classe média e à classe dominante, abraçavam uma causa comum às mulheres de diversos países (...)" (TELES, 1993, p. 51). Nesse contexto, surgem organizações como o Partido Feminino Republicano (fundado em 1910 por Deodolinda Dalho), a Liga para a Emancipação Internacional da Mulher (criada em 1920 por Maria Lacerda de Moura e Bertha Lutz) e a Federação Brasileira pelo Progresso Feminino (organizada em 1922 também por Bertha Lutz).
} 


\section{artigos}

\section{Entre a redação e o set de filmagem}

Em 1975, com patrocínio da Organização das Nações Unidas (ONU), é realizado o seminário "O papel e o comportamento da mulher na realidade brasileira", no Rio de Janeiro. A partir deste evento, surgem grupos de mulheres em várias cidades do país e são criadas condições favoráveis para a criação de uma imprensa alternativa feminista (TELLES, 1993, apud TAMIÃO, 2009, p. 23). Assim, no mesmo ano, nasce o jornal Brasil Mulher, fundado pela Sociedade Brasil Mulher, em Londrina, e focado no movimento pela anistia e na mobilização e cobertura do movimento operário, com destaque às mulheres operárias. No ano seguinte, a Associação de Mulheres cria o periódico Nós Mulheres, com sede da redação em São Paulo. Posteriormente, em 1981, surge, também em São Paulo, o Mulherio, com apoio da Fundação Carlos Chagas e da Fundação Ford.

A imprensa alternativa feminista surge já em um momento de maior abrandamento da censura e não encontramos registros de perseguições aos jornais estudados. Contudo, uma parte considerável de suas editoras estava ligada à militância de esquerda, tendo vivenciado a clandestinidade, a prisão, a tortura e/ou o exílio em momento anterior à criação dos periódicos (FREITAS, 2014, p. 157-158).

Por meio dos jornais, os movimentos feministas conseguiam fazer circular ideias e assuntos que ficavam de fora da imprensa oficial (LEITE, 2003, p. 235), como é ressaltado no editorial da $16^{a}$ edição do Mulherio, que afirmava que o jornal era:

[...] um contraponto aos outros órgãos da imprensa, que em geral tratam a mulher de um modo esquizofrênico: as revistas masculinas mostram a gente nua; as revistas femininas, de avental; os jornais diários, no mais das vezes, nos reduzem à total invisibilidade (a menos que sejamos "estrelas"). E a mulher real, onde é que está? (MULHERIO, mai./jun. 1984, p. 2). 


\section{artigos}

\section{Nayla Tavares Guerra}

Percebe-se, nesse trecho, algumas características próprias aos periódicos, como é o caso da inovação da linguagem e uma abordagem crítica das questões de gênero. A primeira pessoa do plural era frequentemente usada para demarcar que se falava das mulheres a partir das mulheres ${ }^{4}$. Refletindo sobre esse aspecto, Rosalina Leite comenta o título "Quem somos?" do editorial da primeira edição do Nós Mulheres, e afirma que essa opção de linguagem rompia com o papel de um editor impessoal e assexuado que se referia à leitora com o distanciamento do "você, mulher", comum à imprensa feminina tradicional (LEITE, 2003, p. 239).

Assim como havia um contraponto entre a imprensa tradicional e a imprensa alternativa, havia também entre o longa e o curta-metragem. O filme curto atendia aos anseios de um cinema alternativo que expressasse as diferentes vozes que compunham a sociedade brasileira. Devido à especificidade de sua menor duração, ele teve que encontrar novas formas de se estabelecer enquanto gênero.

Durante a segunda metade dos anos 1970 e anos 1980, jovens cineastas independentes travaram uma batalha em prol do curta, por enxergarem nele "uma espécie de antídoto para o veneno que é o imperialismo" (SANTEIRO, apud DEBS, 1989, p. 5). Em diálogo com tal ideia, Aloysio Raulino defendia que o formato fílmico de menor duração teria uma força além, quando comparado aos longas de ficção: "é a tentativa permanente de olhar o mundo à nossa volta, sem disfarces" (RAULINO, apud DEBS, 1989, p. 6).

Se a experimentação de linguagem no âmbito jornalístico era possibilitada pela imprensa alternativa, o caminho para isso no cinema se trilhava entre os curta-

\footnotetext{
${ }^{4}$ As mulheres compunham "os conselhos editoriais dos jornais, sendo responsáveis pela direção política, linha editorial e redação das principais matérias. Tal situação não excluía a colaboração dos homens de diversos modos" (LEITE, 2003, p. 234).
} 


\section{artigos}

\section{Entre a redação e o set de filmagem}

metragens. O afastamento destes em relação à indústria permitia uma maior contestação estilística e ideológica, como aponta Vânia Debs:

[O] investimento relativamente pequeno necessário para a realização desses filmes (se comparado àquele para o longa-metragem) deixa aberta a possibilidade de se estabelecer poucos vínculos com as regras da indústria, com o cinema comprometido com o mercado comercial, constituindo um espaço privilegiado para a experimentação de novos temas e de novas articulações linguísticas (DEBS, 1989, p. 3).

Esse distanciamento do curta-metragem em relação ao cinema comercial também foi fundamental para proporcionar maior abertura desse formato fílmico às mulheres. O menor orçamento - resultado tanto da menor duração, quanto da simplificação do aparato cinematográfico - facilitava (como facilita ainda hoje) que as mulheres, excluídas da indústria, tivessem acesso a esse meio de produção. É, contudo, necessário um adendo com relação às mulheres sobre as quais estamos falando. Trata-se de um grupo muito específico: as mulheres cisgênero brancas e de classe média ou alta. Como comentado, no levantamento de filmes realizado, encontramos 224 curta-metragens feitos por 123 diretoras diferentes entre 1966 e 1985. Destas, todas são cisgênero, poucas são amarelas, apenas uma é negra ${ }^{5}$ e nenhuma é indígena. Lançamos também um olhar para a classe social, que aparenta ser mais abastada, consequência dos empecilhos para conseguir financiamento público para a realização cinematográfica. À época, "para fazer curta você tinha que fazer com o dinheiro do seu próprio bolso" (ROGÉRIO, apud PADOVAN, 2001, p. 39), como relatam algumas diretoras e diretores. Era comum também um esquema de parcerias no qual as pessoas trabalhavam umas para as outras de graça, se

\footnotetext{
${ }^{5}$ Esta é Adélia Sampaio, considerada a primeira mulher negra a dirigir um longa-metragem no Brasil (Amor maldito, 1984). O segundo longa feito por uma mulher negra a estrear comercialmente no Brasil, $O$ caso do homem errado (Camila de Moraes), é de 2017, o que revela a manutenção da disparidade entre mulheres negras e brancas no audiovisual.
} 


\section{artigos}

\section{Nayla Tavares Guerra}

alternando nas equipes dos filmes dos amigos e colegas:

[...] todo mundo trabalhava na base da ajuda de custo, ou de graça, porque daí quando ele fazia o dele, eu trabalhava de graça pra ele. Tinha todo um lance de trocar nesse sentido, e isso viabilizava os filmes, os filmes eram baratos. Se você fosse orçar profissionalmente, seria muito mais caro, e o dinheiro não dava (ROGÉRIO, apud PADOVAN, 2001, p. 44).

Desse modo, a produção de curta-metragens se manteve baseada em pessoas cuja condição financeira permitia investir o tempo em trabalhos não remunerados, ou ainda utilizar dinheiro próprio para a realização artística, situação esta que dificultava o acesso de indivíduos de classes sociais menos abastadas ao fazer cinematográfico.

Entretanto, mesmo para esse grupo de mulheres para as quais o curtametragem abriu portas para a entrada no meio cinematográfico, permaneciam outros desafios, como a realização de um segundo ou terceiro filme. Das 123 cineastas do levantamento, 73 não conseguiram realizar mais de um curta-metragem, como indica o gráfico abaixo:

Número de filmes realizados por número de diretoras

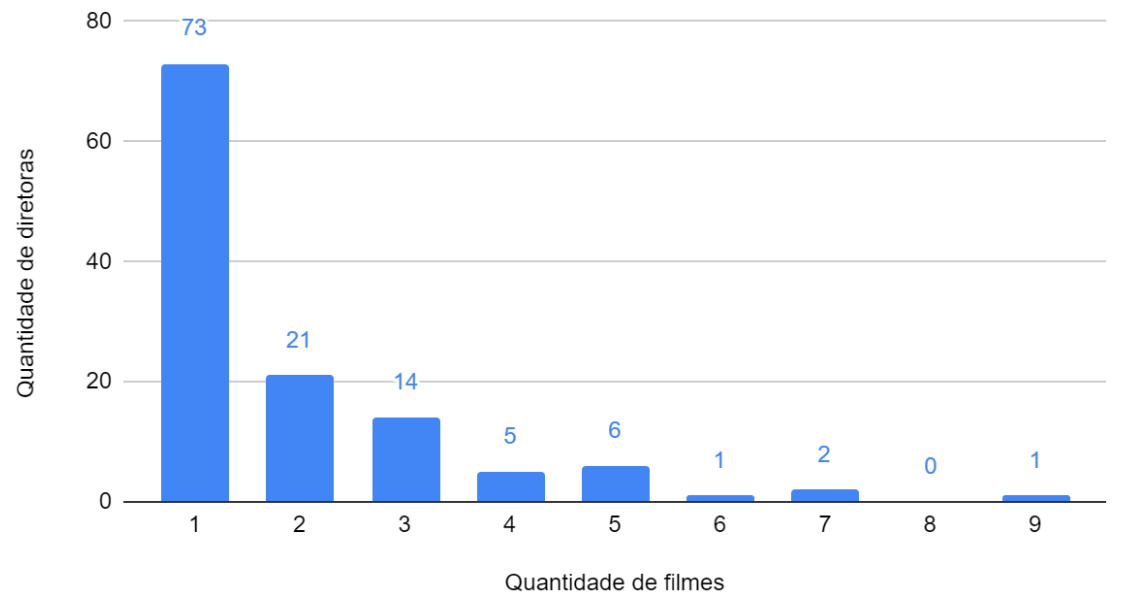

Imagem 1: Gráfico "número de filmes realizados por número de diretoras". Fonte: autoria própria, 2020 


\section{artigos}

\section{Entre a redação e o set de filmagem}

Além disso, raras foram as que conseguiram realizar longa-metragens, um fator importante que revela a dificuldade de acesso às grandes produções. Dentre as poucas que alcançaram tal feito, podemos destacar, além das já mencionadas, Anna Muylaert, Suzana Amaral e Tizuka Yamazaki. Referindo-se aos empecilhos apontados, Inês Castilho, diretora de dois curtas do levantamento (Mulheres da boca, 1981, e Histerias, 1983), afirma em entrevista que:

Não tenho uma carreira cinematográfica, exatamente. Fiz cinema durante alguns anos, na primeira metade dos anos 80 , e nunca mais. Mãe e pai de família, precisava de sustento. A vida falou mais alto - um fato comum na vida das mulheres de cinema (CASTILHO, 2017).

Nessa fala, Castilho demonstra clareza sobre a dificuldade coletiva de acesso das mulheres ao cinema enquanto profissão e aponta o elemento familiar como um dos entraves. A "dupla jornada", ou seja, responsabilidade das mulheres de cuidarem da família e da casa, ainda que com empregos externos ao ambiente doméstico, era e ainda é - um empecilho para as realizadoras, haja vista a demanda por longas horas de trabalho nas gravações dos filmes.

Esse tema foi o foco da primeira edição do Mulherio e era frequente tanto neste jornal, quanto em Nós Mulheres. A própria Inês Castilho, que além de ter dirigido os filmes citados, também escrevia para os dois periódicos, assinou uma matéria sobre maternidade nesta primeira edição do Mulherio, na qual ela coloca que:

Penso, finalmente, que é injusto que seja assim. Que apenas as mulheres sejam responsáveis pela vida e morte, saúde e doença, felicidade ou fatalidade que a vida reserva para nossos filhos. Que os homens assumam tão pouco a paternidade. Que tenham criado uma sociedade onde nos dizem "ser mãe é o principal papel da mulher", não deixando espaço para vivermos nossas outras dimensões (MULHERIO, mai./jun. 1981, p. 9). 


\section{artigos}

\section{Nayla Tavares Guerra}

Em outra matéria, denominada "Mães: difícil lidar com a culpa", algumas mulheres entrevistadas reclamam sobre o fardo da exclusividade materna da criação dos filhos. Várias relatam também remorso e culpa ao terem que deixar os filhos com o pai ou outro membro da família, seja para trabalhar ou para fazer alguma atividade de lazer. Uma das entrevistadas, Marília de Andrade comenta que:

Eu também não consigo me adaptar ao modelo tradicional de mãe. Mas, aparece um grande conflito cada vez que tenho que deixar as crianças, cada dia que não me sobra tempo para supervisionar a lição de casa, etc. Fico racionalizando, me dizendo o tempo todo: "tudo bem, eu tenho que trabalhar, eu estou ocupada, e tal..." Mas, de qualquer jeito, eu me sinto mal. Eu diria que é uma coisa quase que de estômago, que me pega no fundo, sabe? (MULHERIO, nov./dez. 1981, p. 12).

Marília de Andrade também dirigiu alguns curtas presentes no levantamento realizado: É menino ou menina? (1978), Balzaquianas (1981) e A terceira idade (1982). Todos foram codirigidos por Eliane Bandeira e lançam um olhar para questões de gênero. O único cuja cópia conseguimos localizar e assistir é Balzaquianas ${ }^{6}$, uma ficção cujo roteiro foi construído a partir de entrevistas com mulheres casadas de 20 a 40 anos, pertencentes a diferentes classes sociais. Uma mesma atriz (Irene Ravache) interpreta cinco personagens diferentes, apresentando diversas situações cotidianas de subordinação das mulheres ao papel de esposa e mãe.

O filme estava extremamente alinhado às ideias difundidas no Mulherio e, não à toa, foi objeto de uma crítica publicada na já comentada primeira edição do periódico. Sob o título “Balzaquianas: um retrato do casamento", Betty Mindlin escreve que: "dissecado como instituição social, o trabalho doméstico fica absurdo: é feito em tal isolamento que as mulheres ficam cortadas da sociedade, sem campo

\footnotetext{
${ }^{6}$ Filme disponível online no acervo do Museu da Imagem e do Som de São Paulo: <https://acervo.missp.org.br/filme/balzaquianas> Acesso em: 17 jan. 2020.
} 


\section{artigos}

\section{Entre a redação e o set de filmagem}

para ação no mundo" (MULHERIO, mai./jun. 1981, p. 9).

Essa questão é ilustrada em várias cenas do filme, entre elas uma na qual uma mulher lava roupas no tanque, com sua filha pequena. Seu marido aparece e comenta: “O tempo tá feio né? Mas mesmo assim vai dar pra bater uma bolinha... Eu gosto mesmo é de domingo... A gente não tem nada pra fazer...", e em seguida adiciona "Agora vou pro bar, encontrar o pessoal. Capricha no rango hoje, que eu vou trazer o Zé para almoçar ai, viu?". O homem sai e chama o filho pequeno para ir junto, enquanto a mulher e a filha continuam lavando roupas.

A intermitência (para as mulheres) do trabalho doméstico não remunerado e realizado no âmbito privado, em paralelo aos momentos (para os homens) de descanso tanto na esfera pública quanta na privada, revela uma estreita ligação com o pensamento feminista que vinha sendo produzido à época. Em Balzaquianas, a solução temporária encontrada por uma das personagens foi deixar de viajar com a família, alegando: “Eu quero ficar sozinha, quero descansar. Não quero ter o trabalho de ficar cuidando da família nesse feriado".

Tal cena está muito ligado à charge divulgada em uma edição do Mulherio:

\section{Ciça}

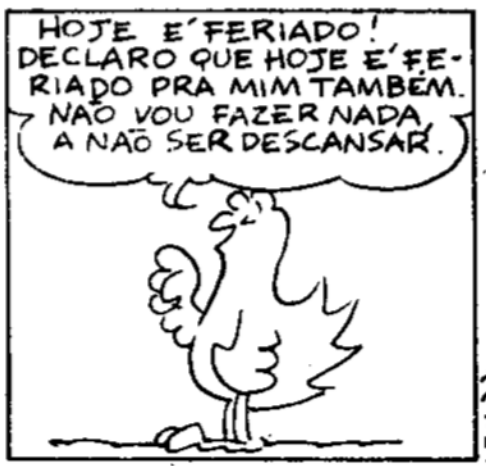

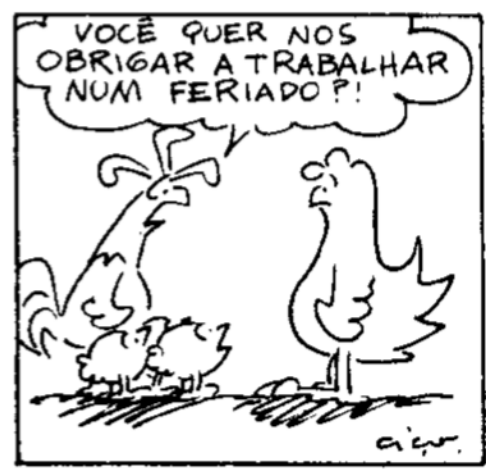




\section{artigos}

\section{Nayla Tavares Guerra}

Imagem 2: Charge "Ciça" publicada no jornal Mulherio, $1981{ }^{7}$

Alinhada às problematizações da associação naturalizada entre mulheres e serviço doméstico estava a luta pelas creches, que ocupou diversas páginas dos dois jornais estudados. Ao mesmo tempo em que havia uma defesa da ocupação do espaço público pelas mulheres e da igualdade salarial, havia a consciência de que, para isso, seria necessário encontrar um local para deixar as crianças, como é colocado em uma das matérias, intitulada "Creche: com quem deixar nossos filhos": “Esta é uma questão que cada vez mais mulheres enfrentam, no momento em que deixam o lar para trabalhar e aumentar o orçamento doméstico. Mas mesmo trabalhando fora, a mulher continua sendo responsável pelo cuidado dos filhos" (NÓs MULHERES, set./out. 1976, p. 10).

Havia, também, uma consciência de que a luta deveria ser por creches públicas, como é evidente na matéria "Mais uma vez: creche!", que chama a atenção para o crescimento desses espaços, porém privados, dificultando o acesso das mulheres pobres. Estas, como é ressaltado, trabalhavam muitas vezes cuidando dos filhos das ricas, mas não recebiam salário suficiente para pagar alguém para cuidar de seus próprios filhos. A matéria adiciona ainda que as mulheres:

Precisam sair para trabalhar fora de casa e, ainda que esse trabalho seja mal remunerado, cansativo e repetitivo, ele é parte importante do longo caminho de libertação das mulheres e do ser humano. [...] Entre os mais pobres, as famílias são centralizadas na mãe, que é quem cuida, mantém e educa as crianças. [...] A creche é desesperadamente necessária para a mulher que trabalha (NÓS MULHERES, ago./set. 1977, p. 11).

Nos curta-metragens, a luta pelas creches aparece em dois filmes: Só o amor

\footnotetext{
${ }^{7}$ A autorização para a reprodução da charge neste artigo foi gentilmente cedida por sua criadora, Cecília Pinto.
} 


\section{artigos}

\section{Entre a redação e o set de filmagem}

não basta (Dilma Lóes, 1977) e Creche-lar (Maria Luíza Aboim, 1979). Ambos abordam a experiência de uma creche comunitária na Vila Kennedy no Rio de Janeiro, solução que se aproximava da defesa da coletivização da reprodução social, da ideia de que a educação das crianças deveria ser discutida "não mais como um assunto privado de cada mulher, mas como um problema da coletividade" (MULHERIO, nov./dez. 1981, p.9), alinhando, mais essa pauta, à ideia de que "o pessoal é político".

\section{Um olhar dos jornais para os curta-metragens}

Além de realizar matérias sobre filmes e diretoras, havia também, em ambos jornais, a divulgação de exibições de obras as quais dialogavam com as pautas do periódico (fossem elas dirigidas por mulheres ou por homens). Com isso, pode-se ter acesso a informações pouco conhecidas sobre a circulação de alguns curta-metragens do levantamento. Há, por exemplo, uma nota denominada “Cinema Debate: A Mulher em São Paulo" (NÓS MULHERES, mar. 1978, p. 7), na qual divulga-se uma exibição do filme Vida de doméstica (Eliane Bandeira, 1976), com a presença da diretora e uma representante da Associação das Empregadas Domésticas. Informações como esta revelam um dado importante de diálogo dos filmes com a conjuntura na qual estavam inseridos: as obras eram não somente influenciadas pelo contexto, como também eram usadas pelos movimentos sociais para promover mudanças nas estruturas.

Esse potencial de transformação social do cinema é ressaltado em uma matéria sobre outra exibição de alguns dos curtas estudados - Menino ou menina (Marília de Andrade, Eliane Bandeira, 1978), A menina e a casa da menina (Maria Helena Saldanha, 1979) e Balzaquianas (Eliane Bandeira, Marília de Andrade, 1981). Sob o título “Mostra 
de filmes na SBPC"'8, lê-se:

O filme, como outras formas de manifestações artísticas, é um veículo privilegiado para mobilizar opiniões e suscitar debates sobre temas de interesse científico. Sem se submeter, necessariamente, aos cânones impostos pela 'verdade' científica, o cinema documentário ou ficcional pode ser, muitas vezes, um retrato mais vivo da realidade, provocando reações que levam as pessoas a repensarem seus conceitos sobre o mundo (MULHERIO, jul./ago. 1981, p. 11).

Além de divulgar exibições, o jornal Mulherio relatava também, com recorrência, a possibilidade de alugar curtas feitos por mulheres e/ou em diálogo com as pautas feministas. Escrevia-se sobretudo sobre a Dinafilmes (Distribuidora Nacional de Filmes) $)^{9}$ e a CDI (Cinema Distribuição Independente) ${ }^{10}$. Nota-se que essas matérias eram direcionadas sobretudo a cineclubes, coletivos e associações de mulheres, incentivando-as a alugarem os filmes e exibirem-nos, com a perspectiva de aprofundarem as discussões relativas a tais pautas:

Você quer alugar filmes sobre mulher para projetar em sua associação, sindicato ou em sua cidade? Agora ficou mais fácil: um grupo de cineastas criou a CDI - Cinema Distribuição Independente, justamente para facilitar o acesso a um cinema que não se vê na televisão e nos circuitos comerciais.

Num catálogo inicial de 140 filmes de curta e longa-metragem sobre vários temas, há oito relacionados diretamente à mulher. São eles Balzaquianas, de Elaine Bandeira e Marília de Andrade, prêmio de Melhor ficção na X Jornada Brasileira de Curta-Metragem; É menino ou menina?, de Elaine Bandeira e Marília de Andrade; Retratos de Hideko, de Olga Futema; Tempo Quente, de Leilany Fernandes Leite, prêmio especial na X Jornada Brasileira de Curta-

\footnotetext{
${ }^{8}$ SBPC - Sociedade Brasileira para o Progresso da Ciência.

${ }^{9}$ A Dinafilmes foi criada em 1976 durante a X Jornada Nacional de Cineclubes em Juiz de Fora (MG). Seu principal objetivo era fortalecer a circulação alternativa dos curta-metragens, facilitando o acesso dos cineclubes. Como a maior parte desses espaços de exibição operava com filmes em 16mm, o catálogo da distribuidora privilegiava essa bitola (MELO, 2018, p. 69).

${ }^{10}$ A CDI foi criada em 1982 por realizadores membros da Associação de Documentaristas de São Paulo. Com o objetivo de exibir filmes que não tinham espaço na televisão ou no circuito comercial, eram distribuídas cópias para escolas, entidades, grupos comunitários, sindicatos, etc. Tratava-se de uma instituição sem fins lucrativos, porém era cobrado um aluguel para a manutenção das cópias e divulgação (SILVA, 2011, p. 75).
} 


\section{artigos}

\section{Entre a redação e o set de filmagem}

Metragem; Tigresa, de Wilson Barros; Trabalhadoras metalúrgicas, de Olga Futema ${ }^{11}$; e Vida de doméstica, de Eliane Bandeira. Depois de divulgado o catálogo, mais dois filmes ficaram prontos: Mulheres da Boca, de Inês Castilho e Cida Aidar, e Terceira idade, de Elaine Bandeira e Marília de Andrade (MULHERIO, jul./ago. 1982, p. 20).

Por fim, para concluir sobre as relações mais gerais entre os curta-metragens estudados e os jornais Nós Mulheres e Mulherio, destaca-se uma matéria intitulada “Mulheres, câmera, ação” (Mulherio, nov./dez. 1981, p. 22). Nela, ressalta-se a produção cinematográfica de mulheres: “De repente as mulheres descobrem o cinema como meio de expressão artística e passam a realizar seus próprios filmes", e chama-se atenção para o fato de que a produção de curtas pelas cineastas estava suprindo uma necessidade de expressão do feminismo no âmbito cultural e artístico. Observa-se, com isso, a consciência das redatoras deste jornal sobre a importância do destaque a filmes não só sobre mulheres, como filmes feitos por mulheres, além da percepção da potência que os curta-metragens poderiam assumir na luta contra o patriarcado e as opressões de gênero, constituindo-se como uma possível ferramenta à luta feminista.

\section{Mulheres da Boca: da redação dos jornais ao set de filmagens}

Mulheres da boca (Cida Aidar, Inês Castilho, 1981) ${ }^{12}$ é um documentário sobre as prostitutas e seus exploradores na Boca do Lixo de São Paulo ${ }^{13}$. Como comentado, Inês Castilho escreveu para os dois jornais sobre os quais nos debruçamos: Nós Mulheres e Mulherio. Em uma entrevista, de 2017, para o site Mulheres do Cinema Brasileiro, Castilho comenta sobre este filme, Mulheres da Boca:

\footnotetext{
${ }^{11}$ Apesar da matéria não mencionar, este filme foi codirigido por Renato Tapajós, como atestam seus créditos.

${ }^{12}$ Filme disponível online no Youtube: <https://www.youtube.com/watch?v=7uOIOle_QSo>Acesso em 17 jan. 2020.

${ }^{13}$ A Boca do Lixo é uma região não oficial do centro da cidade de São Paulo. Com forte presença de prostitutas, entre o final dos anos 1960 e o início dos anos 1980, tornou-se também um reduto do cinema brasileiro independente.
} 


\section{artigos}

\section{Nayla Tavares Guerra}

Cida e eu nos conhecemos no coletivo feminista que editou o jornal Nós Mulheres entre 1976 e 1979. Foi quando o grupo de estudos sobre a mulher da Fundação Carlos Chagas lançou o Concurso de Pesquisa sobre a Mulher, e nós decidimos propor um projeto de filme, ao invés de pesquisa acadêmica. $O$ tema prostituição foi escolhido a partir da cisão na identidade feminina, entre a puta e a santa - cisão hoje relativizada pelas décadas de atuação do feminismo, particularmente a Marchas das Vadias ${ }^{14}$. O projeto é meu e da Cida, mas na esteira do espírito coletivo do feminismo foram incorporadas várias outras mulheres, como se pode ver nos $\operatorname{créditos}^{15}$ (CASTILLO, 2017).

Como apontado anteriormente, ao ler as edições dos jornais Nós Mulheres e Mulherio, foram encontradas publicações sobre diversos filmes presentes no levantamento que realizamos. Uma delas corresponde a uma crítica a Mulheres da boca, escrita por Maria Rita Kehl e publicada no Mulherio (mai./jun. 1982, p. 20). Nela, há um tom elogioso à obra, destacando a aproximação realizada entre as prostitutas e as espectadoras, separadas "apenas" pelo nível sócio-econômico. Chama-se atenção para um retrato singular das prostitutas, que não as erotiza, diferentemente de tantas outras representações dessas mulheres realizadas no cinema e na literatura. Esta visão será comentada mais adiante, por meio da análise do filme.

\footnotetext{
14 A Marcha das Vadias é um movimento surgido a partir de um protesto realizado em abril de 2001 em Toronto, no Canadá. O movimento se internalizou e ocorreu no Brasil pela primeira vez em junho do mesmo ano. Nas Marchas, protesta-se contra a culpabilização das vítimas de estupro feita com o argumento de que elas teriam provocado a violência por meio de suas roupas ou comportamento.

${ }^{15}$ A fim de compreender se uma mulher na direção repercutia em mais mulheres na equipe, realizamos um estudo da composição por gênero das equipes técnicas dos curta-metragens incluídos no levantamento. Averiguamos uma discrepância muito grande, sobretudo nas funções ligadas à fotografia e ao som. Mesmo em filmes com mulheres na direção, a quantidade de outras mulheres nas equipes ainda era muito pequena e, não raro, nula. Todavia, os filmes dirigidos por Inês Castilho estão entre os que apresentam maior proporção de mulheres em relação a homens: Mulheres da boca (codireção de Cida Aidar, 1981), possui 8 mulheres e 5 homens na equipe, e Histerias (1983), possui 9 mulheres e 8 homens.
} 


\section{artigos}

\section{Entre a redação e o set de filmagem}

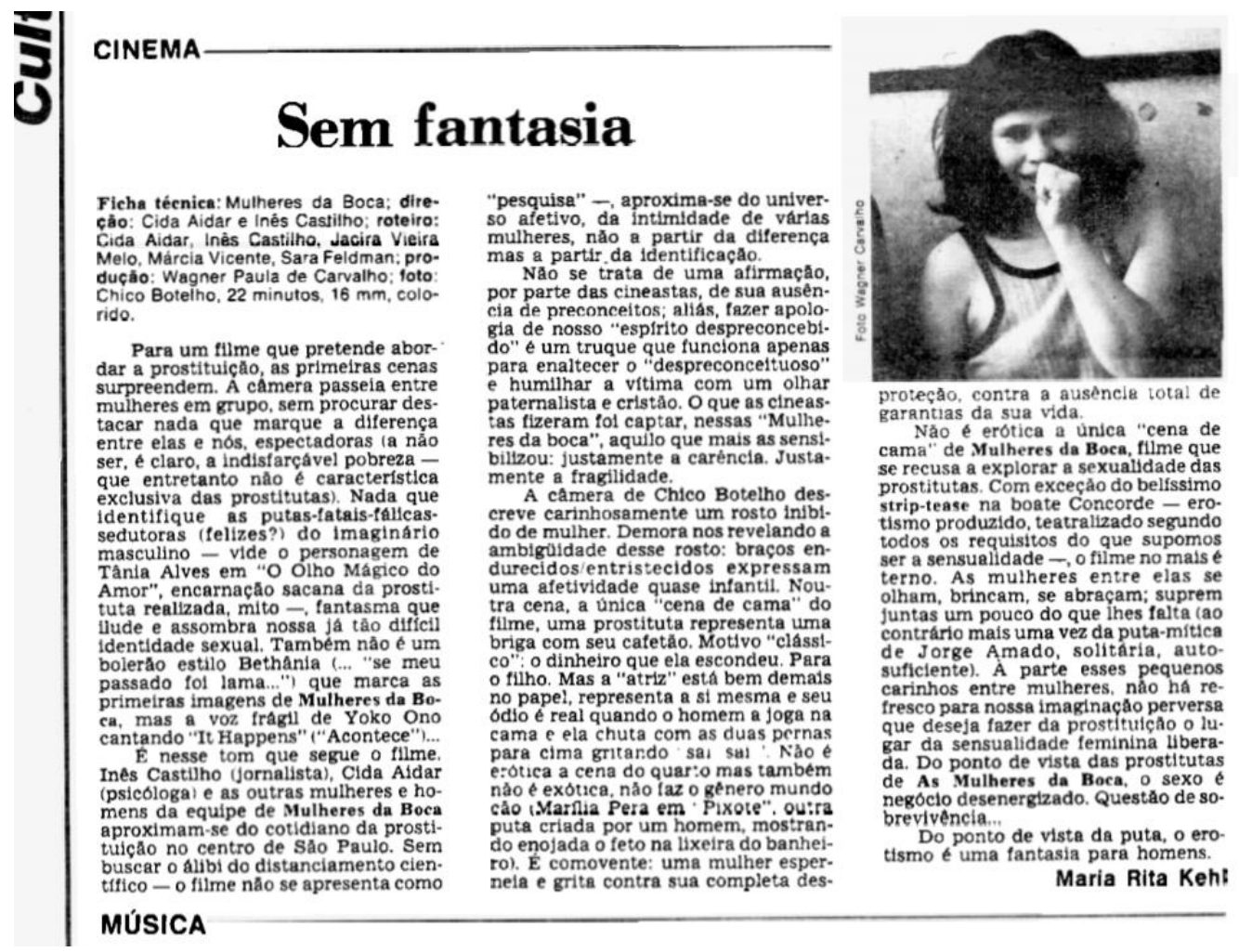

Imagem 3: Crítica do filme Mulheres da boca publicada no jornal Mulherio, 1982

Localizamos também, em algumas edições, tanto no Nós Mulheres quanto no Mulherio, notícias sobre o referido concurso de bolsas de estudo sobre a mulher promovido pela Fundação Carlos Chagas. Em uma das matérias, após ressalva sobre o baixo valor da bolsa, é posto que "Há de se louvar, porém, essa iniciativa das pesquisadoras da Fundação, pois inexistem em nosso país instituições que ofereçam bolsas ou ajudas a pesquisadores sobre o tema" (NÓS MULHERES, jun./jul. 1978, p. 3). Essa colocação, aliada à recorrência de menções a esse concurso em ambos jornais, revela a importância dessa iniciativa para o movimento feminista da época. Em outra publicação, foi encontrada uma menção ao fato de Mulheres da boca ter ganho um dos prêmios:

O segundo concurso, aberto em 1979, mostrou um interesse ainda maior: apresentaram-se 131 projetos, dos quais 19 receberam financiamento de até 


\section{artigos}

\section{Nayla Tavares Guerra}

200 mil cruzeiros. Este concurso revelou grande abertura. Além de cientistas sociais, médicos, engenheiros, arquitetos, advogados e artistas também apresentaram projetos. E, fugindo à tradição acadêmica, uma das 'pesquisas' aprovadas é um filme sobre prostituição, de Inês Castilho, Chico Botelho' ${ }^{16} \mathrm{e}$ Cida Aidar (MULHERIO, mai./jun. 1981, p. 11).

Considerando que Mulheres da boca foi realizado no seio do coletivo que editava o Nós Mulheres, cabe destacar que o jornal também se debruçava sobre o tema abordado no filme (a prostituição). Diante de tal observação, avaliamos as relações entre o posicionamento explicitado na mídia impressa e na obra fílmica. Esta posição pode ser verificada em um pequeno artigo, intitulado '“Protegendo' as prostitutas" (NÓS MULHERES, jun./jul 1978, p. 1):

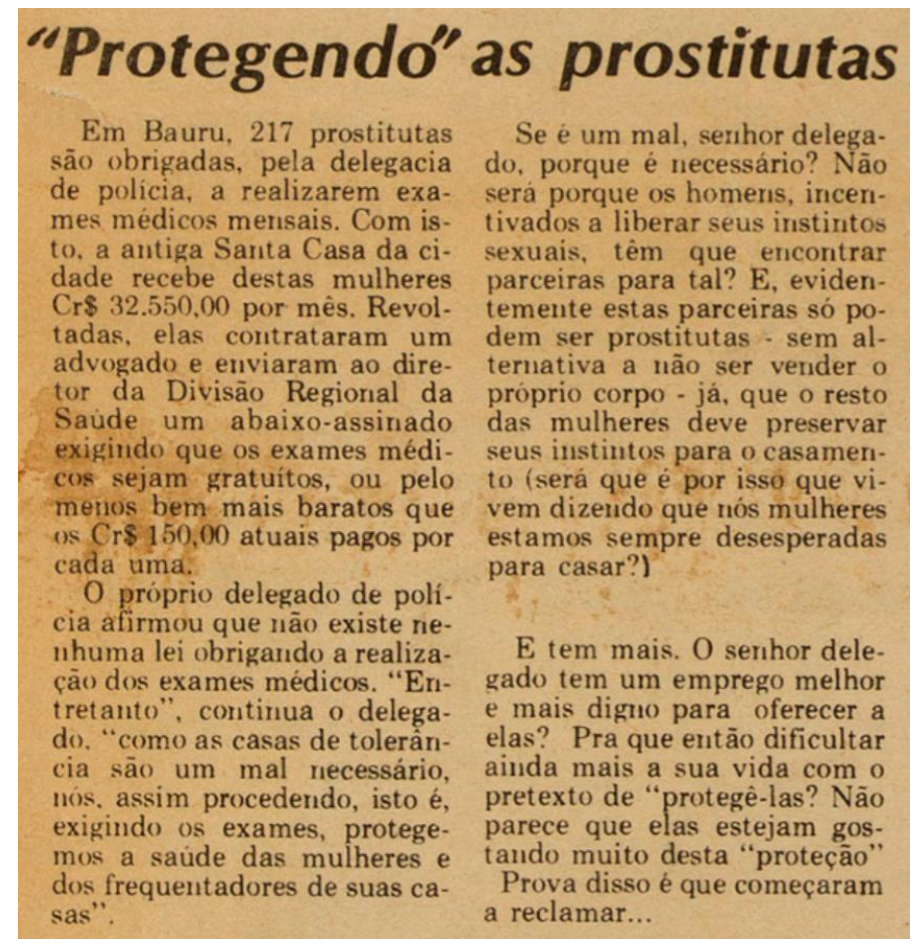

Imagem 4: Publicação sobre prostituição no jornal Nós Mulheres, 1978

Nesta notícia, é aborda a exigência feita por uma delegacia de polícia de Bauru

\footnotetext{
${ }^{16}$ No filme, Chico Botelho não é creditado como codiretor, como realizado aqui. Nos créditos, ele aparece apenas como diretor de fotografia.
} 


\section{artigos}

Entre a redação e o set de filmagem

(São Paulo) para que prostitutas realizassem exames médicos periódicos, pelos quais elas mesmas deveriam pagar. Esta ação revela uma atenção das instituições policiais às prostitutas, que durante o regime militar sofreram intensa repressão por representarem "um crime contra os costumes"17. Na cidade de São Paulo no início dos anos 1980, por exemplo, uma enorme quantidade de prostitutas, travestis e homossexuais foram detidos por rotas promovidas pelo delegado José Wilson Richetti. Com o objetivo de 'limpar' o centro da cidade, de 300 a 500 pessoas eram levadas por dia para a delegacia, sob os fundamentos legais de contravenção penal de vadiagem e de prisão cautelar (BRASIL: CNV, 2014, p. 307). Em um contexto de extrema criminalização da prostituição, tanto a matéria publicada no jornal Nós Mulheres, quanto o filme Mulheres da boca, optam por um caminho contrário, reconhecendo a vulnerabilidade econômica das prostitutas e, com isso, tratando a profissão por elas realizada como uma fatalidade.

No curta-metragem, isso fica evidente na música da sequência de abertura, que, no momento do título, conta "Isso aconteceu em um momento da minha vida, quando eu menos esperava" (tradução nossa) ${ }^{18}$. A montagem vertical associa a frase às "mulheres da boca" (título e categoria social das personagens), revelando a imprevisibilidade e a inevitabilidade da prostituição. Na reportagem, por sua vez, essa ideia é expressa na passagem "evidentemente estas parceiras só podem ser prostitutas - sem alternativa a não ser vender o próprio corpo - [...]", que, entre as escolhas lexicais, utiliza o advérbio de exclusão "só" para enfatizar irremediabilidade da profissão, e o verbo "vender", que reforça o caráter de transação comercial para ressaltar a necessidade financeira de se prostituir.

\footnotetext{
${ }^{17}$ Expressão utilizada pelo delegado José Wilson Richetti em diversas entrevistas dadas para os jornais à época.

18 Trecho da música It happened, de Yoko Ono. Trecho original: "It happened at a time of my life when I least expected".
} 


\section{artigos}

\section{Nayla Tavares Guerra}

Além disso, tanto na obra cinematográfica quanto na peça jornalística, por falarem a um terceiro sujeito - que difere tanto das prostitutas, quanto das diretoras/jornalistas - há um tom informativo e, ao mesmo tempo, de denúncia da precariedade daquela realidade. No filme, nota-se isso por meio da câmera que adentra lentamente o prédio no qual trabalham e residem e revela a pobreza do espaço sujo e quebrado. Na matéria do periódico, por sua vez, o tom mencionado é percebido na explicitação da fala do delegado seguida do uso da ironia ("Se é um mal, senhor delegado, por que é necessário?").

As primeiras mulheres que aparecem no filme são filmadas andando na rua. A câmera na mão acompanha o movimento delas com um plano próximo, focado em seus rostos (imagens 5, 6 e 7). Os planos são curtos; cada um com uma ou duas mulheres. Esses enquadramentos, que se concentram nos rostos e as filmam individualmente, trazem uma carga subjetiva para as personagens, o que é feito antes da cartela de título e de outras informações que revelem a profissão por elas exercida. Esta estratégia colabora para humanizá-las, retratadas antes que o público saiba que se trata de mulheres que se prostituem, evitando distanciamento decorrente dos estigmas associados a sua profissão. Por outro lado, mesmo trazendo a subjetividade pela expressão facial, ela não permeia completamente a estrutura do filme, uma vez que não é dada às filmadas a oportunidade de falarem. Assim, elementos ainda mais subjetivos e individuais, como traços de personalidade e opiniões, são deixados de fora. 


\section{artigos}

\section{Entre a redação e o set de filmagem}

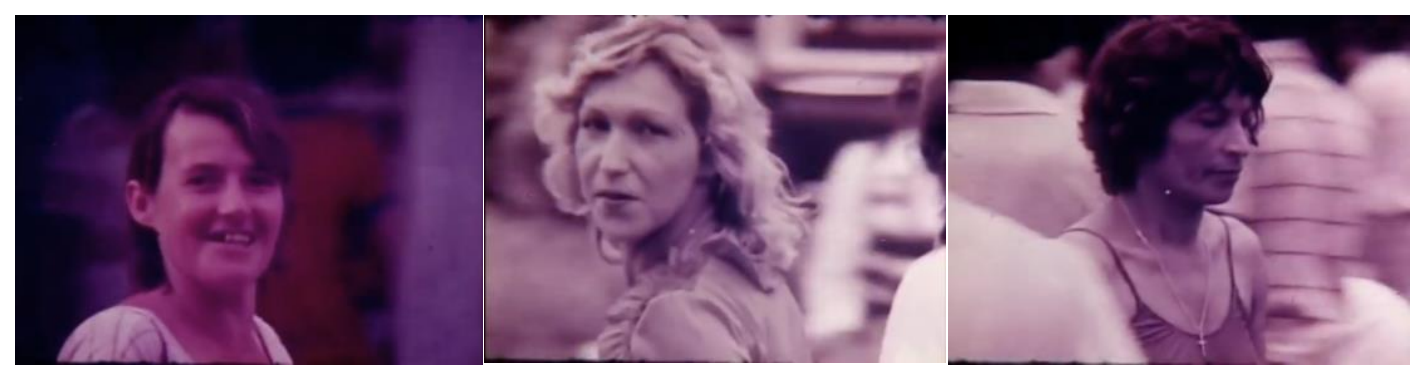

Imagem 5: 00min40 ${ }^{19}$

Imagem 6: 00min51

Imagem 7: 00min54

A dicotomia colocada, relacionada a uma subjetivação que se limita à visualidade das "mulheres da boca", se estende para todo o filme. As únicas pessoas com espaço de fala de fato são uma cafetina e um cafetão. Ambos são entrevistados e têm longa sequência de fala garantida pela montagem. A cafetina (cujo nome não aparece na sequência) comenta sobre sua relação com as prostitutas, conta como chegou até o "lenocínio" (palavra usada por ela) e conversa sobre sua vida amorosa, que inclui um relacionamento antigo com um policial. Ela termina afirmando que sente, enquanto sua obrigação de comerciante, presentear espontaneamente o chefe de distrito, aos finais de ano, "com uma camisa de seda, um litro de whisky de categoria", para "quando tiver um imprevisto, ou qualquer pressão, que não é novidade", poder "bater um fio pro distrito" e ter "uma equipe de segurança à sua disposição". As palavras em itálico (obrigação, presentear, espontaneamente) evidenciam um mascaramento do suborno realizado, enquanto as expressões adverbiais (aos finais de ano, que não é novidade) indicam uma recorrência das ações. Desse modo, a cafetina expõe os mecanismos pelos quais se aproxima dos agentes da lei (o relacionamento com o policial e o suborno) que lhe permitem coordenar um esquema ilegal de comercialização dos corpos, a prostituição.

\footnotetext{
${ }^{19}$ As imagens reproduzidas a seguir são fotogramas retirados do filme Mulheres da Boca, para complementar as análises desenvolvidas. A autorização para sua reprodução neste artigo foi gentilmente cedida por Inês Castilho, codiretora da obra.
} 


\section{artigos}

\section{Nayla Tavares Guerra}

A "equipe de segurança à disposição" é o gancho para a introdução de outra figura: um cafetão. Quinzinho, nome repetido diversas vezes na sequência, aparece em um bar, jogando sinuca com outros homens, pedindo mais doses da cachaça 51, e afirmando, para o dono do bar, que "pode chamar a polícia, que ninguém vai pagar nada". Há aqui, novamente, a banalização de um ato ilegal (consumir e não pagar) e a consciência da impunidade, provavelmente porque ele sabe que os agentes da lei estarão do seu lado, ainda que cometa uma infração.

Após essa fala, começa a entrevista de fato. Vemos uma mulher com um microfone, que questiona "Quem é o Quinzinho?". Essa pergunta é fundamental, pois, a partir dela, o entrevistado pode escolher o que falar sobre si, como se apresentar, o que revelar de sua construção enquanto sujeito. Quinzinho comenta de onde veio seu apelido; conta como virou "o Rei da Boca"; brinca com os assassinatos do ROTA ${ }^{20}$ e do tático móvel, que seria então "o rei", ao matar 30 pessoas por dia; e, por fim, fala sobre um prédio que teve no qual controlava mais de 300 mulheres. A entrevista é entrecortada por planos nos quais Quinzinho interage com outros homens num bar, enquanto joga sinuca e baralho.

Observa-se que, por meio das falas da cafetina e de Quinzinho, conseguimos conhecer uma série de informações sobre a subjetividade dos dois, que seriam muito mais difíceis de serem apreendidas caso o filme se limitasse a mostrá-los visualmente. Às "mulheres da boca”, por sua vez, não é dada a oportunidade de se colocarem verbalmente. Não sabemos seus nomes (aliás, o único nome que aprendemos durante toda a obra é o de Quinzinho), suas histórias, suas opiniões,

\footnotetext{
${ }^{20}$ A Rondas Ostensivas Tobias de Aguiar (ROTA) é uma tropa do Comando Geral da Polícia Militar do Estado de São Paulo, modalidade de policiamento pertencente ao $1^{\circ}$ Batalhão de Policiamento de Choque Tobias de Aguiar. Foi criada em 1970 para combater guerrilhas urbanas e, com o fim destas ainda no início da década, passou a reprimir crimes comuns. A ROTA ficou famosa por sua extrema violência e grande número de assassinatos.
} 


\section{artigos}

\section{Entre a redação e o set de filmagem}

suas reflexões. Tudo que sabemos sobre elas é reduzido ao que podemos ver delas. Isso é particularmente delicado dado o apego à imagem exigido pela profissão que exercem, na qual são frequentemente restringidas ao próprio corpo, sendo a mente e o intelecto pouco ou nada valorizados. Ao se limitar a apenas mostrá-las, sem escutálas, o curta-metragem corrobora para a construção identitária das mulheres prostituídas baseada unicamente em sua imagem.

Após a cartela do título, há uma cena na qual um cafetão e uma das "mulheres da boca" estão no quarto. Na crítica citada, escrita por Maria Rita Kehl e publicada no jornal Mulherio, esta cena é descrita como uma ficção da realidade: "uma prostituta representa ${ }^{21}$ uma briga com seu cafetão". De fato, a proximidade física e a intimidade da câmera com tal situação de violência levam a imaginar que esta foi (re)criada para ser filmada naquele momento. Usa-se aqui o prefixo re-, entre parêntesis, pois o realismo das ações e das reações da personagem transmitem a sensação de que aquela mulher provavelmente já viveu algo muito parecido, encenando, assim, uma situação real e abalando com isso os limites entre documentário e ficção.

Nesta cena, a personagem mulher é o foco. Na maior parte do tempo ela é enquadrada de frente e no centro do quadro, enquanto o cafetão é filmado de costas e no canto (imagem 8). Ademais, as atuações expõem contrastes: de um lado, tem-se a vulnerabilidade da mulher, reforçada pelo fato de ela permanecer quase em silêncio, com a cabeça abaixada e ombros caídos, e, de outro, a agressividade verbal e física do homem, que segura violentamente o rosto dela. Estes procedimentos técnico-formais colaboram para a afeição do público com a mulher prostituída e repulsa pelo cafetão. Isso é reforçado pela escolha da montagem de colocar essa

\footnotetext{
${ }^{21} \mathrm{O}$ destaque à palavra "representa" não estava presente na escrita original, porém foi dado aqui para enfatizar o caráter ficcional da cena, defendido na crítica citada.
} 


\section{artigos}

Nayla Tavares Guerra

sequência logo após aquela que contém os planos próximos dos rostos e a música de Yoko Ono. Se por um lado há uma ruptura de tom (melodia suave da música e planos próximos de várias mulheres sorrindo na rua versus a violência sofrida pela mulher no quarto), há uma intensificação do sentimento de empatia que vinha sendo construído e favorece o repúdio pela violência representada.

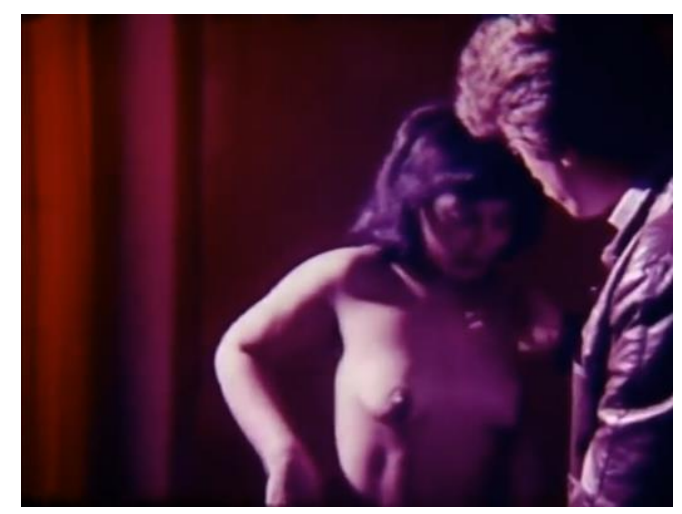

Imagem 8: $2 \min 59$

Em um dos momentos finais da película, retrata-se uma boate de strip-tease. Esta cena difere radicalmente da proposta estética e poética da primeira comentada. Se, no início do filme, há uma tentativa de subjetivar as "mulheres da boca", aqui há a manutenção de algumas problemáticas de representação de uma mulher no cinema. Ainda que o filme em questão seja um documentário, nesse momento há a reprodução de códigos visuais e narrativos típicos do cinema clássico, sobretudo no que diz respeito à decupagem e à montagem.

Nota-se uma aproximação entre o olhar do público da boate (majoritariamente formado por homens) e o olhar do espectador 22 . Isso acontece, pois a câmera adota o

\footnotetext{
${ }^{22}$ Usa-se o substantivo "espectador", no masculino, neste momento, pois apesar de imaginar que o filme tenha sido visto tanto por homens quanto por mulheres, em uma sociedade patriarcal que abafa o discurso e o desejo feminino, o olhar das mulheres é muitas vezes também "masculinizado".
} 


\section{artigos}

Entre a redação e o set de filmagem

ponto de vista desse público sobre as dançarinas. Elas estão em cima de um palco, enquanto este está sentado, portanto em um nível espacial mais baixo. A filmagem das dançarinas em contra-plongée $e^{23}$ e da plateia na altura dos olhos revela um posicionamento de câmera muito mais próximo fisicamente das pessoas que assistem do que das mulheres que dançam (imagens 9 e 10).

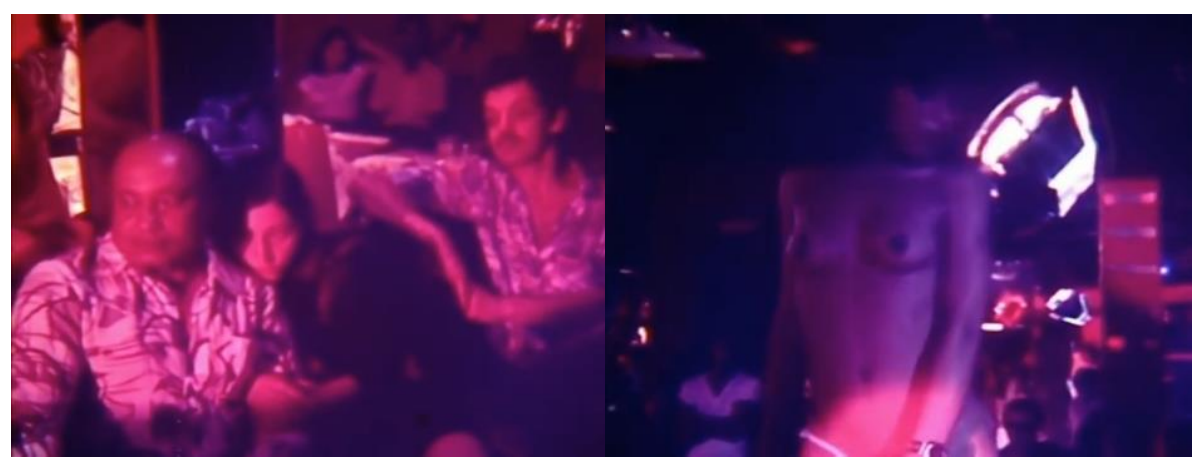

Imagem 9: $14 \min 12$

Imagem 10: $14 \min 30$

Ademais, há diversos inserts de contra-planos do rosto do público a olhar para elas, mas não há contra-planos dos rostos delas olhando para a plateia. Inclusive, as dançarinas aparecem frequentemente 'decapitadas' em quadro, anulando completamente não só seu olhar, como toda sua subjetividade facial. Esses contraplanos são intercalados com planos próximos de partes fragmentadas dos corpos das mulheres que são culturalmente erotizadas (imagens 11, 12 e 13). Esses procedimentos técnico-formais estabelecem quem deve ser olhada, quem deve olhar, como deve olhar e para onde deve-se olhar. Com isso, o espectador, que também realiza a ação de olhar para o filme, tende a se identificar, independentemente de seu gênero, com o público e não com as dançarinas.

\footnotetext{
${ }^{23}$ Termo utilizado no cinema para se referir aos planos filmados "de baixo para cima", isto é, com a câmera apontando para um nível mais alto do que aquele onde ela está.
} 


\section{artigos}

Nayla Tavares Guerra

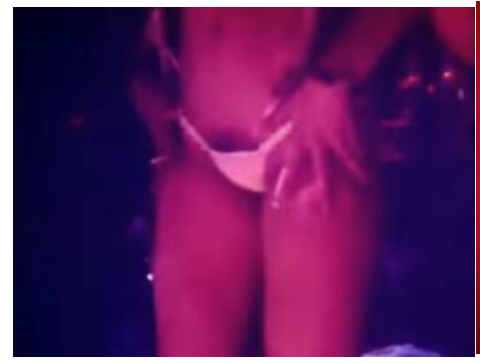

Imagem 11: 12min10

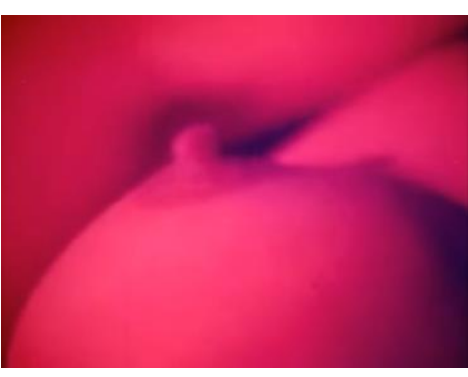

Imagem 12: 12min43

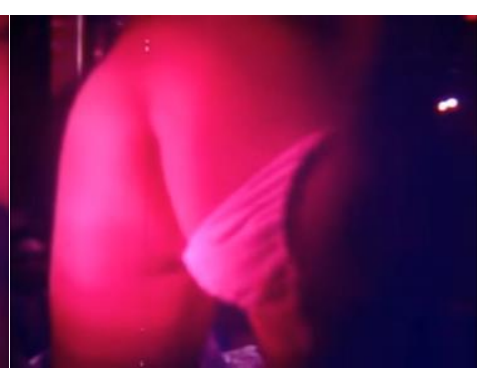

Imagem 13: 14min25

Se o sujeito é quem pratica a ação e o objeto é o que a sofre, considerando que o público da boate olha e elas são olhadas, essa dinâmica de olhares colabora para acentuar o peso da objetificação das mulheres filmadas. Elas são aqui portadoras e não produtoras de significado. Nesse sentido, o olhar construído na cena é indissociado de uma submissão de quem é olhada, uma vez que restringe os corpos de mulheres à posição de desencadeadores de desejo, retirando deles a possibilidade de existirem unicamente para si, além de suprimir a possibilidade das mulheres de tornarem-se sujeitos desejantes.

Essa análise contradiz o que é colocado por Maria Rita Kehl em sua crítica. Segundo ela, o filme se recusa a explorar a sexualidade das prostitutas e não as erotiza, uma vez que "[d]o ponto de vista da puta, o erotismo é uma fantasia para homens". Como mostramos, na sequência analisada o ponto de vista construído pelos elementos técnico-formais não é o da puta, mas o dos homens que as erotizam e objetificam. Desse modo, nesse momento da obra, as mulheres filmadas parecem existir, tanto no espaço físico da boate de strip-tease, quanto na sequência do filme, apenas para a satisfação de quem as olha, seja esse sujeito o público-personagem da cena ou o público-espectador do curta-metragem.

Nesse cenário, a decupagem e a montagem funcionam como uma autorização formal para que as mulheres em cena sejam olhadas. O uso de planos frontais e sem 


\section{artigos}

Entre a redação e o set de filmagem

função narrativa (meramente contemplativos), como o plano detalhe da cintura, dos mamilos e da bunda (imagens 11, 12 e 13), intensifica o tom exibicionista da cena (que já estava posto pela presença do palco e a dinâmica do espaço onde as imagens foram gravadas). Os corpos dessas mulheres são, assim, transformados em espetáculo e, “(e)m seu tradicional papel exibicionista, as mulheres são vistas e exibidas simultaneamente, com o seu aspecto codificado para um forte impacto visual e erótico, de modo que se pode dizer que elas são conotações a serem consideradas" (MULVEY, 1988, p. 62, tradução nossa).

Há, nessa cena, a presença de estímulos à escopofilia, definida como "prazer em usar outra pessoa como objeto de estimulação sexual através da visão" (MULVEY, 1988, p. 61, tradução nossa). Assim, elas são aqui objetos eróticos do olhar da plateia, da câmera e, consequentemente, do espectador, mantendo-se subordinadas a esses três componentes.

Observa-se, portanto, uma dicotomia entre as sequências iniciais do filme e esta, que é uma das últimas. Em um primeiro momento, os diversos elementos da linguagem cinematográfica são usados para colocar as mulheres prostituídas em um espaço outro daquele tradicionalmente associado a elas e criar uma empatia entre elas e as espectadoras e os espectadores. Já no final, esses elementos acentuam a identificação da espectatorialidade com o público da boate e não com as dançarinas, rompendo com a dinâmica inicial de identificação/empatia. Ademais, enquanto a primeira sequência foca nos rostos e expressões faciais das "mulheres da boca", reforçando visualmente a subjetividade e individualidade, neste outro momento elas aparecem, diversas vezes, decapitadas em quadro, e a fragmentação de seus corpos colabora para uma visão redutora delas não como um todo, mas como uma junção de partes sexualizadas. 


\section{artigos}

\section{Nayla Tavares Guerra}

Laura Mulvey aponta que um dos desafios de se lutar contra a estrutura inconsciente da linguagem (a cinematográfica, no caso analisado) é desatrelar-se da linguagem do patriarcado (1988, p. 58). Tendo isso em vista, percebe-se que Mulheres da boca não consegue transcender completamente a esse sistema de opressão, pois utiliza, em alguns momentos do filme, a linguagem criada por ele, criando ambiguidades e estranhamentos.

\section{Conclusão}

Ao nos debruçarmos sobre os curta-metragens feitos por diretoras brasileiras durante a ditadura civil-militar, encontramos uma série de relações com a imprensa alternativa feminista. Os jornais Nós Mulheres e Mulherio permitiram traçar paralelos entre as pautas do movimento de contestação de mulheres e filmes presentes no levantamento fílmico realizado. A partir dos periódicos, identificamos também informações relativas à divulgação e distribuição das obras estudadas. Além disso, pudemos analisar o olhar dos jornais para os filmes através das críticas fílmicas publicadas em algumas edições. Deste modo, o uso de Nós Mulheres e Mulherio como material de pesquisa permitiu o aprofundamento das relações entre os filmes que abordavam gênero e seu contexto de produção e de circulação.

Observamos que a película Mulheres da boca representou uma união entre a imprensa alternativa feminista e os curta-metragens feitos por diretoras brasileiras, a partir da intersecção entre a figura da jornalista e da cineasta. Assim como outras obras cinematográficas, como Balzaquianas e Creche-lar, ela revela um interesse de algumas das mulheres ligadas ao movimento feminista de segunda onda em utilizar o cinema como plataforma de comunicação das pautas e questões discutidas, sejam elas ligadas à prostituição, à luta por creches públicas, à dupla jornada de trabalho ou 


\section{artigos}

Entre a redação e o set de filmagem

às opressões vivênciadas pelas mulheres nas relações conjugais. Se nos jornais estes temas são discutidos de modo bastante informativo e argumentativo, nos filmes a arte traz também uma dimensão poética, criada pelos mais diversos elementos da linguagem cinematográfica (trilha sonora, fotografia, direção de arte, etc.).

A imprensa alternativa e o curta-metragem configuram-se como produtos menos valorizados dentro de seus campos (jornalístico e cinematográfico), em comparação com a imprensa oficial e o longa-metragem. Talvez por isso, foi neles que as mulheres encontraram um espaço maior para se colocarem como jornalistas e como diretoras, além de lograrem dialogar sobre questões relacionadas a suas vivências, opressões e lutas. Portanto, os meios de comunicação produzidos e distribuídos à margem de um circuito hegemônico, por vezes invisível tanto para os censores da época quanto para os pesquisadores de depois, foram fundamentais para a expressão, a circulação e o registro histórico do pensamento ligado ao movimento da segunda onda feminista no Brasil.

\section{Periódicos}

NÓS MULHERES, ano 1 a 3, n. 2 a 8, set./out. 1976 a jun./jul. 1978. Disponível em <https://www.fcc.org.br/conteudosespeciais/nosmulheres/>. Acesso em: 7 fev. 2020.

MULHERIO, ano 1 a 16 - mar./abr. 1981 a mai./jun. 1984. Disponível em <https://www.fcc.org.br/conteudosespeciais/mulherio/capas2.html> Acesso em: 7 fev. 2020.

\section{Referências bibliográficas}

BRASIL, Comissão Nacional da Verdade. Texto 7 - Ditadura e homossexualidades. In:

Relatório: textos temáticos / Comissão Nacional da Verdade. Brasília: CNV, 2014. 
Nayla Tavares Guerra

CASTILHO, Inês. Mulheres do Cinema Brasileiro. Disponível em: <https://www.mulheresdocinemabrasileiro.com.br/site/entrevistas depoimentos/visu aliza/213/Ines-Castilho> Acesso em: 15 jul. 2019.

CAVALCANTE, Alcilene. Cineastas brasileiras (feministas) durante a ditadura civilmilitar. In: HOLANDA, Karla; TEDESCO, Marina Cavalcanti (Orgs.). Feminino e plural: mulheres no cinema brasileiro. Campinas: Papirus, 2017, p. 59-76.

COSTA, Ana Alice Alcântara. O feminismo brasileiro em tempos de ditadura. In: PEDRO, Joana Maria; WOLFF, Cristina Scheibe (Orgs.). Gênero, feminismos e ditaduras no Cone Sul. Santa Catarina: Editora Mulheres, 2010.

DEBS, Vânia Fernandes. Curta-Metragem: Trajetória dos anos 80. Tese (Doutorado em Cinema) - Escola de Comunicação e Artes, Universidade de São Paulo, São Paulo, 1989.

FREITAS, Viviane Gonçalves. O jornal Mulherio e sua agenda feminista: primeiras reflexões à luz da teoria política feminista. História, histórias, Brasília, v. 2, n. 4, 2014.

HOLANDA, Karla. Cinema brasileiro (moderno) de autoria feminina. In:

TEDESCO, Marina Cavalcanti (Orgs.). Feminino e plural: mulheres no cinema brasileiro. Campinas: Papirus, 2017, p. 43-58.

LEITE, Rosalina da Santa Cruz. Brasil Mulher e Nós Mulheres: origens da imprensa feminista brasileira. Revista Estudos Feministas, v. 11, n. 1, jan./jun. 2003, p. 234 241.

MELO, Izabel de Fátima Cruz. Cinema, circuitos culturais e espaços formativos: novas sociabilidades e ambiência na Bahia (1968-1978). Tese (Doutorado em Ciências) - Escola de Comunicações e Artes, Universidade de São Paulo, São Paulo, 2018.

MULVEY, Laura. Visual pleasure and narrative cinema. In: PENLEY, Constance (Org.). Feminism and film theory. Nova York: Routledge, 1988, p.57-68.

PADOVAN, Carlos José. Audácia e diversidade: curta-metragem e o Prêmio Estímulo (1968-84). Dissertação (Mestrado em Multimeios) - Instituto de Artes, Universidade Estadual de Campinas, Campinas, 2001.

SILVA, Denise Tavares da. Vida Ionga ao curta. Dissertação (Mestrado em Multimeios) - Instituto de Artes, Universidade Estadual de Campinas, Campinas, 1999. 


\section{artigos}

\section{Entre a redação e o set de filmagem}

SILVA, Francine Nunes da. Práticas do dizer, práticas do fazer: cineclubismo, imagens e política. Dissertação (Mestrado em Ciências Sociais) - Centro de Ciências Sociais e Humanas, Universidade Federal de Santa Maria, Santa Maria, 2011.

TAMIÃO, Juliana Segato. Escritas feministas: os jornais Brasil Mulher, Nós Mulheres e Mulherio (1975-1988). Dissertação (Mestrado em História Social) - Pontifícia Universidade Católica de São Paulo, São Paulo, 2009.

TELES, Maria Amélia de Almeida. Uma breve história do feminismo no Brasil. São Paulo: Brasiliense, 1993.

VEIGA, Ana Maria. Cineastas brasileiras em tempos de ditadura: Cruzamento, fugas, especificidades. Tese (Doutorado em História) - Centro de Filosofia e Ciências Humanas, Universidade Federal de Santa Catarina, Florianópolis, 2013.

\section{Referências audiovisuais}

A entrevista. Direção: Helena Solberg. Produção: Helena Solberg e Mair Tavares. Rio de Janeiro: CAIC - Comissão de Ajuda à Indústria Cinematográfica, 1966. 20 min., son., $\mathrm{BP}, 16 \mathrm{~mm}$.

BALZAQUIANAS. Direção: Eliane Bandeira e Marília de Andrade. Produção: Rogério Corrêa. São Paulo: NAU - Nacional Artistas Unidos; Secretaria Estadual de Cultura Conselho Estadual de Artes e Ciências Humanas - Comissão de Cultura, 1981. 20 min., son., COR, $16 \mathrm{~mm}$.

CRECHE - lar. Direção: Maria Luíza Aboim. Produção: Flávia Behmer. Rio de Janeiro: Corcina - Cooperativa dos Realizadores Cinematográficos Autônomos Ltda, 1979. 9 min., son., COR, $16 \mathrm{~mm}$.

MULHERES da boca. Direção: Cida Ainda e Inês Castilho. Produção: Wagner Carvalho e Sara Feldman. São Paulo: Tatu Filmes; Embrafilme - Empresa Brasileira de Filmes S.A., 1981. 21 min., son., COR, $16 \mathrm{~mm}$.

SÓ o amor não basta. Direção: Dilma Lóes. Produção: Dilma Lóes, M. Santana e Lydia Mattos. Rio de Janeiro: Dilma Lóes e Afko Produções Cinematográfica, 1977. Son., COR, $16 \mathrm{~mm}$.

THE emerging woman. Direção: Helena Solberg. Nova Iorque: International Cinema, 1974. 40min., son., BP, $16 \mathrm{~mm}$. 


\section{artigos}

Nayla Tavares Guerra

Imagens

Imagem 1: Autoria própria. Gráfico "número de filmes realizados por número de diretoras", 2020.

Imagem 2: MULHERIO. Charge “Ciça” publicada no jornal Mulherio, ano 1, n. 0, mar./abr. 1981, p. 4.

Imagem 3: MULHERIO. Crítica do filme Mulheres da boca publicada no jornal Mulherio, ano 2, n. 7, mai./jun. 1982, p. 20.

Imagem 4: NÓS MULHERES. Publicação sobre prostituição no jornal Nós Mulheres, ano 3, n. 8, jun./jul. 1978, p. 1.

Imagens 5 a 13: Fotogramas do filme Mulheres da Boca (Inês Castilho, Cida Aidar, 1981). 